\title{
Isolation, Characterization, Complete Structural Assignment, and Anticancer Activities of the Methoxylated Flavonoids from Rhamnus disperma Roots
}

\author{
Hamdoon A. Mohammed 1,2,*iD, Mohammed F. Abd El-Wahab ${ }^{2}$, Usama Shaheen ${ }^{2}$, Abd El-Salam I. Mohammed ${ }^{2}$, \\ Ashraf N. Abdalla ${ }^{3,4}\left(\mathbb{D}\right.$ and Ehab A. Ragab ${ }^{2, *}$ \\ 1 Department of Medicinal Chemistry and Pharmacognosy, College of Pharmacy, Qassim University, \\ Buraydah 51452, Saudi Arabia \\ 2 Department of Pharmacognosy, Faculty of Pharmacy, Al-Azhar University, Cairo 11371, Egypt; \\ mohabdelwahab@yahoo.com (M.F.A.E.-W.); Usamayosef2003@yahoo.com (U.S.); \\ ami07@fayoum.edu.eg (A.E.-S.I.M.) \\ 3 Department of Pharmacology and Toxicology, Faculty of Pharmacy, Umm Al-Qura University, \\ Makkah 21955, Saudi Arabia; ashraf_abdalla@hotmail.com \\ 4 Department of Pharmacology and Toxicology, National Center for Research, Khartoum 2404, Sudan \\ * Correspondence: ham.mohammed@qu.edu.sa (H.A.M.); ar_ehab@yahoo.com (E.A.R.)
}

Citation: Mohammed, H.A.; Abd El-Wahab, M.F.; Shaheen, U.; Mohammed, A.E.-S.I.; Abdalla, A.N.; Ragab, E.A. Isolation,

Characterization, Complete

Structural Assignment, and

Anticancer Activities of the Methoxylated Flavonoids from Rhamnus disperma Roots. Molecules 2021, 26, 5827. https://doi.org/ $10.3390 /$ molecules 26195827

Academic Editor: Silvie Rimpelová

Received: 24 August 2021

Accepted: 20 September 2021

Published: 26 September 2021

Publisher's Note: MDPI stays neutral with regard to jurisdictional claims in published maps and institutional affiliations.

Copyright: (c) 2021 by the authors. Licensee MDPI, Basel, Switzerland. This article is an open access article distributed under the terms and conditions of the Creative Commons Attribution (CC BY) license (https:/ / creativecommons.org/licenses/by/ $4.0 /)$.
Abstract: Different chromatographic methods including reversed-phase HPLC led to the isolation and purification of three $O$-methylated flavonoids; 5,4'-dihydroxy-3,6,7-tri-O-methyl flavone (penduletin) (1), 5,3'-dihydroxy-3,6,7,4', 5' -penta-O-methyl flavone (2), and 5-hydroxy-3,6,7,3', 4', 5' 'hexa-O-methyl flavone (3) from Rhamnus disperma roots. Additionlly, four flavonoid glycosides; kampferol 7-O- $\alpha$-Lrhamnopyranoside (4), isorhamnetin-3-O- $\beta$-D-glucopyranoside (5), quercetin 7-O- $\alpha$-L-rhamnopyranoside (6), and kampferol 3, 7-di-O- $\alpha$-L-rhamnopyranoside (7) along with benzyl-O- $\beta$-D-glucopyranoside (8) were successfully isolated. Complete structure characterization of these compounds was assigned based on NMR spectroscopic data, MS analyses, and comparison with the literature. The O-methyl protons and carbons of the three $O$-methylated flavonoids (1-3) were unambiguously assigned based on 2D NMR data. The occurrence of compounds 1, 4, 5, and 8 in Rhamnus disperma is was reported here for the first time. Compound 3 was acetylated at 5-OH position to give 5-O-acetyl-3,6,7,3', $4^{\prime}, 5^{\prime}-$ hexa-O-methyl flavone (9). Compound 1 exhibited the highest cytotoxic activity against MCF 7, A2780, and HT29 cancer cell lines with $\mathrm{IC}_{50}$ values at $2.17 \mu \mathrm{M}, 0.53 \mu \mathrm{M}$, and $2.16 \mu \mathrm{M}$, respectively, and was 2-9 folds more selective against tested cancer cell lines compared to the normal human fetal lung fibroblasts (MRC5). It also doubled MCF 7 apoptotic populations and caused $\mathrm{G}_{1}$ cell cycle arrest. The acetylated compound 9 exhibited cytotoxic activity against MCF 7 and HT29 cancer cell lines with $\mathrm{IC}_{50}$ values at $2.19 \mu \mathrm{M}$ and $3.18 \mu \mathrm{M}$, respectively, and was $6-8$ folds more cytotoxic to tested cancer cell lines compared to the MRC5 cells.

Keywords: Rhamnus disperma; flavonoids; methoxylated flavonoids; cytotoxicity; apoptosis; cell cycle

\section{Introduction}

Rhamnus is a genus of about 110 species of shrubs or small- to medium-sized deciduous or evergreen trees, which are native from temperate to tropical regions and commonly known as buckthorns in the family Rhamnaceae [1,2]. Rhamnus disperma Ehrenb belongs to the family and is a native plant to the northern Middle East and Arabian Peninsula, including Saudi Arabia [3], Syria, Lebanon, Palestine, and considered one of Rhamnus species in the flora of Egypt [1,4]. The plant is reported to contain flavonoids, flavonoid glycosides, and phenolic constituents [5,6]. The Rhamnus species is reported for several biological activities including antioxidant, anti-acetylcholinesterase [7,8], anti-inflammatory, cytotoxic $[9,10]$, and antimicrobial activities [11,12]. 
The present study reported the isolation and structure characterization of three O-methylated flavonoids (compounds 1-3), four flavonoid glycosides (compounds 4-7), and one benzyl glucoside (compound 8) from the roots of Rhamnus disperma (Figure 1). The compounds' cytotoxic activity against human breast adenocarcinoma (MCF 7), human ovary adenocarcinoma (A2780), human colon adenocarcinoma (HT 29) cell lines, and normal human fetal lung fibroblast (MRC5) was evaluated in the current work. The study also demonstrated the synthesis and characterization of the 5-O-acetylated product of compound 3 (compound 9, Figure 1). The cytotoxic activity of compound 9 was also investigated against MCF 7, HT 29, and MRC5 cell lines as a part of the current study.<smiles>COc1cc2oc(-c3ccc(O)cc3)c(OC)c(=O)c2c(O)c1OC</smiles><smiles>CC1CO[C@@H](Oc2cc(O)c3c(=O)c(O)c(-c4ccc(O)cc4)oc3c2)[C@H](O)[C@H](O)[C@H]1O</smiles><smiles>COc1cc(-c2oc3cc(O)cc(O)c3c(=O)c2OC2C[C@@H](O)[C@@H](O)[C@H](CO)CO2)ccc1O</smiles>

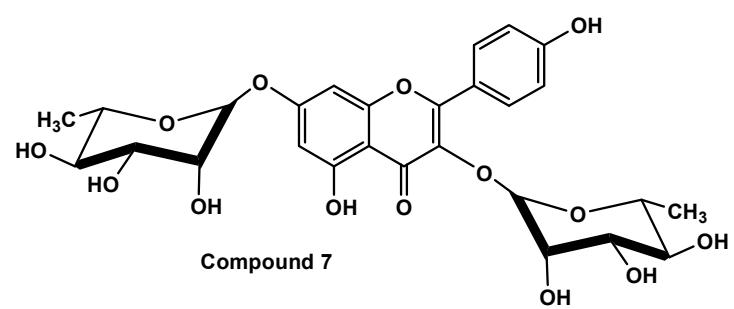<smiles>[R]c1cc(-c2oc3cc(OC)c(OC)c([R])c3c(=O)c2OC)cc(OC)c1OC</smiles>

$\begin{array}{lll} & \mathrm{R}_{1} & \mathrm{R}_{2} \\ \text { Compound 2 } & \mathrm{H} & \mathrm{OH} \\ \text { Compound 3 } & \mathrm{H} & \mathrm{OCH}_{3} \\ \text { Compound 9 } & \mathrm{COCH}_{3} & \mathrm{OCH}_{3}\end{array}$

Figure 1. Chemical structures of compounds 1-9.

\section{Results and Discussion}

The ethyl acetate fraction of the alcoholic extract of Rhamnus disperma roots was repeatedly subjected to silica gel column chromatography ( $\mathrm{Si}$ gel $\mathrm{CC}$ ) to afford seven fractions (A-G). Fraction A was subjected to Si gel CC followed by HPLC analysis and separation yielding compounds $\mathbf{1}-\mathbf{3}$. Fractions $\mathrm{F}$ and $\mathrm{G}$ were subjected to $\mathrm{SPE}-\mathrm{C}_{18}$ column followed by Si gel CC and sephadex LH-20 to give compounds 4-8 (Figure 1). The occurrence of compounds $1,4,5$, and 8 are reported in the current work for the first time from Rhamnus disperma. Although, compounds 2, 3, 6, and 7 were previously isolated from the same plant $[5,13]$. The current work revised the chemical shifts of the $O$-methyl protons and carbons of the methoxyl groups of compounds 1-3. The structures of the methoxylated flavonoids (1-3) were also confirmed through the unambiguous assignment based on 2D NMR data (spectra available in the Supplementary Materials). Furthermore, 
compound 3 was acetylated to give compound 9 , which was identified through $1 \mathrm{D}$ and 2D NMR analyses.

Compound (1) was obtained as yellow crystals and its ${ }^{1} \mathrm{H}$ and ${ }^{13} \mathrm{C}$ NMR data revealed that it is a methoxylated flavonoid. The ${ }^{1} \mathrm{H}$ NMR spectrum of $\mathbf{1}$ showed three methoxyl groups which was evident from the three sharp protons signals at $\delta_{\mathrm{H}} 3.92$ (7-OMe), 3.80 (3-OMe), and $3.74(6-\mathrm{OMe})$, which correlated in the HSQC spectrum to the corresponding methoxyl carbons at $\delta_{C} 57.0,60.2$, and 60.5 , respectively. The location of the methoxy groups in 1 was deduced from the following HMBC correlations: $3 \mathrm{H}$ signal at $\delta_{\mathrm{H}} 3.80$ with $\mathrm{C}-3\left(\delta_{\mathrm{C}} 138.1\right)$, $3 \mathrm{H}$ signal at $\delta_{\mathrm{H}} 3.74$ with $\mathrm{C}-6\left(\delta_{\mathrm{C}} 132.1\right)$, and $3 \mathrm{H}$ signal at $\delta_{\mathrm{H}} 3.92$ with $\mathrm{C}-7\left(\delta_{\mathrm{C}} 159.1\right)$. The downfield shift of $C-2\left(\delta_{C} 156.5\right)$ and $C-3\left(\delta_{C} 138.1\right)$ confirmed the position of the C-3 methoxylated aromatic carbon. Furthermore, the HMBC correlations between $\mathrm{H}-8\left(\delta_{\mathrm{H}} 6.89\right)$ and $C-6\left(\delta_{C} 132.1\right), C-7\left(\delta_{C} 159.1\right), C-9\left(\delta_{C} 152.3\right)$, and $C-10\left(\delta_{C} 106.1\right)$ confirmed the position of the C-6 and C-7 methoxylated aromatic carbons.

Compound (2) was obtained as yellow crystals and its ${ }^{1} \mathrm{H}$ and ${ }^{13} \mathrm{C}$ NMR data revealed that it is also a methoxylated flavonoid. The ${ }^{1} \mathrm{H}$ NMR spectrum of $\mathbf{2}$ showed five methoxyl protons at $\delta_{\mathrm{H}} 3.90(3 \mathrm{H}, \mathrm{s}, 7-\mathrm{OMe}), 3.85\left(3 \mathrm{H}, \mathrm{s}, 5^{\prime}-\mathrm{OMe}\right), 3.80(3 \mathrm{H}, \mathrm{s}, 3-\mathrm{OMe}), 3.77(3 \mathrm{H}, \mathrm{s}$, $\left.4^{\prime}-\mathrm{OMe}\right)$, and $3.72(3 \mathrm{H}, \mathrm{s}, 6-\mathrm{OMe})$, which correlated in the HSQC spectrum to the corresponding methoxyl carbons at $\delta_{C} 56.9,56.5,60.4,60.6$, and 60.6 , respectively. The location of the methoxyl groups in $\mathbf{2}$ was deduced from the following $\mathrm{HMBC}$ correlations: $3 \mathrm{H}$ signal at $\delta_{\mathrm{H}} 3.80$ with $\mathrm{C}-3\left(\delta_{\mathrm{C}} 138.9\right)$, $3 \mathrm{H}$ signal at $\delta_{\mathrm{H}} 3.72$ with $\mathrm{C}-6\left(\delta_{\mathrm{C}} 132.1\right)$, $3 \mathrm{H}$ signal at $\delta_{\mathrm{H}} 3.90$ with $C-7\left(\delta_{C} 159.3\right), 3 \mathrm{H}$ signal at $\delta_{\mathrm{H}} 3.77$ with $\mathrm{C}-4^{\prime}\left(\delta_{\mathrm{C}} 139.5\right)$, and $3 \mathrm{H}$ signal at $\delta_{\mathrm{H}} 3.85$ with $C-5^{\prime}\left(\delta_{C} 153.5\right)$. The position of the methoxylated aromatic carbons at $C-3, C-6$, and C-7 was established as in compound 1 from the downfield shift of C-2 $\left(\delta_{C} 155.8\right)$ and C-3 $\left(\delta_{C} 138.9\right)$, and from the HMBC correlations between $\mathrm{H}-8\left(\delta_{\mathrm{H}} 6.83\right)$ and $\mathrm{C}-6\left(\delta_{\mathrm{C}} 132.1\right), \mathrm{C}-7$ $\left(\delta_{C} 159.3\right), C-9\left(\delta_{C} 152.3\right)$, and $C-10\left(\delta_{C} 106.1\right)$. However, the HMBC correlation between H- 5 hydroxyl proton at $\delta_{H} 12.49$ and C-5 $\left(\delta_{C} 152.0\right), C-6\left(\delta_{C} 132.1\right)$, and C-10 $\left(\delta_{C} 106.1\right)$ established the position of C-6 methoxylated aromatic carbon. Furthermore, the position of the methoxylated aromatic carbons at $\mathrm{C}-4^{\prime}$ and $\mathrm{C}-5^{\prime}$ was evident from the following HMBC correlations: H-2' signal at $\delta_{\mathrm{H}} 7.27$ with C-2 ( $\left.\delta_{\mathrm{C}} 155.8\right), \mathrm{C}-1^{\prime}\left(\delta_{\mathrm{C}} 125.4\right), \mathrm{C}-3^{\prime}\left(\delta_{\mathrm{C}} 151.0\right), \mathrm{C}-4^{\prime}$ $\left(\delta_{C} 139.5\right)$, and $C-6^{\prime}\left(\delta_{C} 104.4\right)$; and the correlation between the $\mathrm{H}-6^{\prime}$ signal at $\delta_{\mathrm{H}} 7.19$ with $C-2\left(\delta_{C} 155.8\right), C-1^{\prime}\left(\delta_{C} 125.4\right), C-3^{\prime}\left(\delta_{C} 151.0\right) C-4^{\prime}\left(\delta_{C} 139.5\right)$, and $C-5^{\prime}\left(\delta_{C} 153.5\right)$.

Compound (3) was obtained as pale-yellow amorphous powder. The NMR data of 3 indicated that, it is a methoxylated flavonoid similar to that of $\mathbf{2}$ except the presence of an additional methyl group in 3 . Its ${ }^{1} \mathrm{H}$ NMR spectrum of 3 showed six methoxyl protons at $\delta_{\mathrm{H}} 3.84(3 \mathrm{H}, \mathrm{s}, 3-\mathrm{OMe}), 3.73(3 \mathrm{H}, \mathrm{s}, 6-\mathrm{OMe}), 3.92(3 \mathrm{H}, \mathrm{s}, 7-\mathrm{OMe}), 3.88\left(6 \mathrm{H}, \mathrm{s}, 3^{\prime}, 5^{\prime}-\mathrm{OMe}\right)$, and $3.77\left(3 \mathrm{H}, \mathrm{s}, 4^{\prime}-\mathrm{OMe}\right)$ which correlated in the HSQC spectrum to the corresponding methoxyl carbons at $\delta_{\mathrm{C}} 60.4,60.5,57.0,56.9$, and 60.7 , respectively. The location of the methoxyl groups in 3 was deduced from the following HMBC correlations: 3Hsignal at $\delta_{\mathrm{H}} 3.84$ with $C-3\left(\delta_{C} 139.0\right), 3 \mathrm{H}$ signal at $\delta_{\mathrm{H}} 3.73$ with $\mathrm{C}-6\left(\delta_{\mathrm{C}} 132.1\right), 3 \mathrm{H}$ signal at $\delta_{\mathrm{H}} 3.92$ with $\mathrm{C}-7$ $\left(\delta_{\mathrm{C}} 159.3\right), 3 \mathrm{H}$ signal at $\delta_{\mathrm{H}} 3.77$ with $\mathrm{C}-4^{\prime}\left(\delta_{\mathrm{C}} 140.5\right)$, and $6 \mathrm{H}$ signal at $\delta_{\mathrm{H}} 3.88$ with $\mathrm{C}-3^{\prime} / 5^{\prime}$ $\left(\delta_{C}\right.$ 153.3). In a similar pattern to compound 2 , the position of the methoxylated aromatic carbons at C-3, C-6, and C-7 was established from the downfield shift of C-2 $\left(\delta_{C} 156.0\right)$ and $C-3\left(\delta_{C} 139.0\right)$, and from the HMBC correlations between H-5 hydroxyl proton at $\delta_{\mathrm{H}} 12.51$ and $\mathrm{C}-5\left(\delta_{\mathrm{C}} 152.0\right), \mathrm{C}-6\left(\delta_{\mathrm{C}} 132.1\right)$, and C-10 $\left(\delta_{\mathrm{C}} 106.2\right)$; and the correlation between $\mathrm{H}-8\left(\delta_{\mathrm{H}} 6.93\right)$ and the $\mathrm{C}-6\left(\delta_{\mathrm{C}} 132.1\right), \mathrm{C}-7\left(\delta_{\mathrm{C}} 159.3\right), \mathrm{C}-9\left(\delta_{\mathrm{C}} 152.3\right)$, and $\mathrm{C}-10\left(\delta_{\mathrm{C}} 106.2\right)$. Furthermore, the position of the methoxylated aromatic carbons at C-3'/C-4' and C-5' was evident from the following HMBC correlations: $\mathrm{H}-2^{\prime} / \mathrm{H}-6^{\prime}$ signal at $\delta_{\mathrm{H}} 7.39$ with $\mathrm{C}-2$ $\left(\delta_{C} 156.0\right), C-1^{\prime}\left(\delta_{C} 125.5\right)$, and $C-2^{\prime}$ or $C-6^{\prime}\left(\delta_{C} 106.4\right), C-3^{\prime}$ or $C-5^{\prime}\left(\delta_{C} 153.3\right)$, and $C-4^{\prime}$ $\left(\delta_{C} 140.5\right)$.

Compound (4) was obtained as yellow amorphous powder. The ${ }^{1} \mathrm{H}$ NMR spectrum of compound 4, showed two meta-coupled proton signals at $\delta 6.41(1 \mathrm{H}, J=1.8 \mathrm{~Hz})$ and $6.82(1 \mathrm{H}, J=1.8 \mathrm{~Hz})$, corresponding to $\mathrm{H}-6$ and $\mathrm{H}-8$ of the A-ring protons, respectively. A typical $\mathrm{AA}^{\prime} \mathrm{BB}^{\prime}$ system at $\delta 8.10 \mathrm{ppm}\left(2 \mathrm{H}, \mathrm{d}, J=8.5 \mathrm{~Hz}, \mathrm{H}-2^{\prime}, \mathrm{H}-6^{\prime}\right)$ and $\delta 6.93(2 \mathrm{H}, \mathrm{d}$, $\left.J=8.8 \mathrm{~Hz}, \mathrm{H}-3^{\prime}, \mathrm{H}-5^{\prime}\right)$ confirmed the 1,4-disubstituted B-ring. These data in addition to the 
ion peak at $m / z 286$ in EIMS, indicated that the aglycon of 4 is kampferol [14]. The anomeric proton signal at $\delta_{\mathrm{H}} 5.54$ (brs, $\left.\mathrm{H}-1^{\prime \prime}\right)$, in addition to the one doublet at $\delta_{\mathrm{H}} 1.11(\mathrm{~J}=6.6 \mathrm{~Hz}$, $\left.\mathrm{H}-6^{\prime \prime}\right)$ observed in the ${ }^{1} \mathrm{H}$ NMR spectrum of compound 4 established the presence of one rhamnose unit. The anomeric configuration for the rhamnose moiety was established to be in the $\alpha$-configuration from its chemical shift and ${ }^{3} J_{\mathrm{H} 1, \mathrm{H} 2}$ coupling constant [15]. The downfield shifts of H-6 and H-8 of the aglycone compared to those of H-6 and H-8 of kampferol indicates that rhamnose moiety was attached to the C-7 position [16-18]. Therefore, compound 4 was established as kampferol 7-O- $\alpha$-L-rhamnopyranoside and in good agreement with the reported literature [19].

Compound (5) was obtained as yellow amorphous powder and was identified as isorhamnetin-3-O- $\beta$-D-glucopyranoside based on comparison of its NMR $\left({ }^{1} \mathrm{H}\right.$ and $\left.{ }^{13} \mathrm{C}\right)$ and EIMS data with those of the literature [17].

Compound (6) was obtained as yellow amorphous powder and its ${ }^{1} \mathrm{H}$ NMR spectrum was similar to that of compound 4, except for B-ring protons which appear as an $\mathrm{ABX}$ system in $6\left[\left(\delta_{\mathrm{H}} 7.72\left(1 \mathrm{H}, \mathrm{d}, J=2.0 \mathrm{~Hz}, \mathrm{H}-2^{\prime}\right), 7.59\left(1 \mathrm{H}, \mathrm{dd}, J=8.3,1.5 \mathrm{~Hz}, \mathrm{H}-6^{\prime}\right)\right.\right.$, and $\left.6.89\left(1 \mathrm{H}, \mathrm{d}, J=8.7 \mathrm{~Hz}, \mathrm{H}-5^{\prime}\right)\right]$ instead of $\mathrm{AA}^{\prime} \mathrm{BB}^{\prime}$ system in 4 . This indicated the presence of 1,3,4-trisubstituted B-ring in compound 6 versus 1,4-disubstituted B ring in compound 4 . These data indicated that the aglycone of 6 is a quercetin [14] which confirmed by the observed ion peak at $m / z 302$ in EIMS spectrum of $\mathbf{6}$. The ${ }^{1} \mathrm{H}$ NMR spectrum of $\mathbf{6}$ exhibited one anomeric proton signal at $\delta_{\mathrm{H}} 5.55$ (brs, $\left.\mathrm{H}-1^{\prime \prime}\right)$ and the strong sharp doublet signal at $\delta_{\mathrm{H}} 1.13 \mathrm{ppm}\left(3 \mathrm{H}, \mathrm{d}, J=6.1 \mathrm{~Hz}, 6^{\prime \prime}-\mathrm{CH}_{3}\right)$ confirmed the rhamnose unit. From the abovementioned data, compound 6 was established as quercetin-7-O- $\alpha$-L-rhamnopyranoside and in good agreement with the reported literatures [19].

Compound (7) was obtained as yellow amorphous powder. The NMR data of the compound revealed the presence of dirhamnoside moieties attached to the kampferol aglycone. The compound was similar to compound 4 by having kampferol as an aglycone and one rhamnose unit at C-7 position in addition to another rhamnose unit at the C-3 position in compound 7. Therefore, compound 7 was identified as kampferol 3, 7-di-O- $\alpha$-Lrhamnopyranoside based on the comparison of its ${ }^{1} \mathrm{H}$ and ${ }^{13} \mathrm{C}$ NMR EIMS data with those of the literature [17].

Compound (8) was obtained as colorless oil and identified as benzyl-O- $\beta$-D-glucopyranoside based on comparison of its ${ }^{1} \mathrm{H},{ }^{13} \mathrm{C}$ NMR, and EIMS data with those of literature [19-21].

Compound (9) was obtained as pale-yellow amorphous powder. The ${ }^{1} \mathrm{H}$ NMR spectrum of the acetylated compound 9 showed an aromatic singlet at $\delta_{\mathrm{H}} 7.38$ corresponding to $\mathrm{H}-8$ proton of $\mathrm{A}$ ring and $\mathrm{H}-2^{\prime} / \mathrm{H}-6^{\prime}$ equivalent protons of $\mathrm{B}$ ring as indicated from HSQC correlation with C-8 $(\delta 99.6)$ and $C-2^{\prime} / C-6^{\prime}\left(\delta_{C} 106.3\right)$. The six methoxyl groups were observed at $\delta_{\mathrm{H}} 3.77$ (s, 3-OMe), $3.74(\mathrm{~s}, 6-\mathrm{OMe}), 4.00$ (s, 7-OMe), 3.89 (s, 3', 5'-OMe), and $3.77\left(\mathrm{~s}, 4^{\prime}-\mathrm{OMe}\right)$ which correlated to the corresponding methoxyl carbons at $\delta_{\mathrm{C}} 60.2,61.5$, $57.3,56.6$, and 60.7, respectively, as showed in the HSQC spectrum. The observed ${ }^{1} \mathrm{H}$ NMR singlet at $\delta_{\mathrm{H}} 2.39$ and ${ }^{13} \mathrm{C}$ NMR signals at $\delta_{\mathrm{C}} 21.2$ and $\delta_{\mathrm{C}} 169.4$ indicated the presence of an acetyl group in 9 . The lack of the hydrogen-bonded $\mathrm{C}-5$ hydroxyl group signal and the downfield shift of $\mathrm{H}-8\left(\delta_{\mathrm{H}} 7.38\right)$ compared to $\mathrm{H}-8\left(\delta_{\mathrm{H}} 6.93\right)$ of 3 together with the downfield shift of C-5 (153.0) and the upfield shift of C-4 carbonyl (172.6) compared to C-5 (152.0) and C-4 carbonyl (178.8) of 3 confirmed the acetylation of C-5 hydroxyl group in $\mathbf{9}$. Therefore, the structure of 9 was identified as 5-O-acetyl-3,6,7,3', $4^{\prime}, 5^{\prime}$-hexa-O-methyl flavone.

\section{Cytotoxicity Assay}

The result of MTT cytotoxicity assay of compounds $1-3$ showed variable $\mathrm{IC}_{50}$ values against the three tested cancer cells ranging from $0.53 \mu \mathrm{M}$ to $9.07 \mu \mathrm{M}$. However, other isolated compounds 4-7 did not show any inhibition of the cancerous cells proliferation at the tested concentrations. Among the three active compounds, compound 3 showed $\mathrm{IC}_{50}$ values of $2.76 \pm 0.16,3.73 \pm 1.75$, and $2.71 \pm 1.25 \mu \mathrm{M}$ against the MCF 7, A2780, and HT 29 cancer cell lines, respectively, and it was $4-5$ folds more cytotoxic against cancer cell lines compared to the human fetal lung fibroblasts (MRC5) normal cells. Compound 2 was 
less active compared to compound 3 , as it exhibited $\mathrm{IC}_{50}$ value ranged from $6.81 \mu \mathrm{M}$ to $9.07 \mu \mathrm{M}$ against the three cancerous cell lines, and it was not selective for MRC5 normal cells as it showed $\mathrm{IC}_{50}$ value of $5.46 \pm 1.57 \mu \mathrm{M}$ against the normal MRC5 cells. Among the three methoxylated flavonoids, compound 1 showed the highest inhibition activity against both MCF 7 and HT 29 cells ( $\mathrm{IC}_{50}$ value of $\leq 2 \mu \mathrm{M}$ ), and A2780 cells ( $\mathrm{IC}_{50}$ value of $0.53 \pm 0.45 \mu \mathrm{M})$. Importantly, compound 1 also showed 2-9 folds lower cytotoxicity against MRC 5 cells with growth inhibition $\mathrm{IC}_{50}$ value of $4.40 \pm 1.45 \mu \mathrm{M}$ (Table 1). Following the process of acetylation, compound 9 was tested against MCF7 and HT29 cell lines. It showed $\mathrm{IC}_{50}$ values in the range of $2-3 \mu \mathrm{M}$. It is slightly more active than its precursor, compound 3, against the MCF 7 cell line. Compound 9 was also 6-8 folds less cytotoxic to MRC5 cells compared to tested cancer cell lines (Table 1). The overall results showed for the higher cytotoxic activity of compounds 1-3 and 9 compared to the other flavonoids (compounds 4-7) are mostly attributed to the presence of the methoxyl moities in the former group of compounds. This claim is completely supported by the literature which proves that poly methoxylated flavonoid derivatives are more potent as cytotoxic agents and have higher ability to inhibit the tumor cells than the flavonoid derivatives with free hydroxylated groups [22-24]. The literature also concluded that methoxy-flavonoids showed remarkable chemo-protective properties and are potentially useful as anticancer agents [25].

Table 1. Activity of the half-maximal inhibitory concentration $\left(\mathrm{IC}_{50} \mu \mathrm{M} \pm \mathrm{SD} ; 72 \mathrm{~h}\right.$ ) of compounds 1-3 and 9 against three cancer cell lines and one normal fibroblast cell line evaluated by MTT assay (72 h).

\begin{tabular}{ccccc}
\hline Compounds & MCF 7 & A2780 & HT 29 & MRC5 \\
\hline $\mathbf{1}$ & $2.17 \pm 0.26$ & $0.53 \pm 0.45$ & $2.16 \pm 0.02$ & $4.40 \pm 1.45$ \\
$\mathbf{2}$ & $6.81 \pm 0.04$ & $8.97 \pm 1.72$ & $9.07 \pm 0.22$ & $5.46 \pm 1.57$ \\
$\mathbf{3}$ & $2.76 \pm 0.16$ & $3.73 \pm 1.75$ & $2.71 \pm 1.25$ & $11.73 \pm 1.58$ \\
$\mathbf{9}$ & $2.190 \pm 0.64$ & - & $3.18 \pm 0.64$ & $19.04 \pm 2.98$ \\
\hline
\end{tabular}

Apoptosis was quantified by detecting cell surface exposure of phosphatidylserine (PS) in apoptotic cells using annexin V PI/FITC. Living cells stained with neither of the two dyes (PI-/annexin V-), while early apoptotic cells stain only with annexin $\mathrm{V}(\mathrm{PI}-$ /annexin $\mathrm{V}+)$. In late apoptosis, cell membrane integrity is lost allowing penetration of PI (PI+/annexin V+); while in necrosis (death), cells stain with PI only (PI+/annexin V-). In this study, compound $\mathbf{1}$ induced remarkable apoptosis in a dose dependent manner (Figure 2).

The cell cycle is a series of changes occurring from the initial phase of cell formation leading to its division as a consequence of a specific mechanism. Cell cycle phases include $\mathrm{G}_{1}$ (gap 1), $\mathrm{S}$ (synthesis), $\mathrm{G}_{2}$ (gap 2), and $\mathrm{M}$ (mitosis), with cell cycle arrest usually taking place in the $\mathrm{G}_{1} / \mathrm{S}$ or the $\mathrm{G}_{2} / \mathrm{M}$ check points. Compound 1 was used to treat the MCF 7 cell line ( $24 \mathrm{~h} ; 5 \mu \mathrm{M}, 10 \mu \mathrm{M}$, and $20 \mu \mathrm{M}$ ) to investigate possible cell cycle effect. Compared to the control, compound $\mathbf{1}$ caused dose-dependent $\mathrm{G}_{1}$ arrest (Figure 3). 

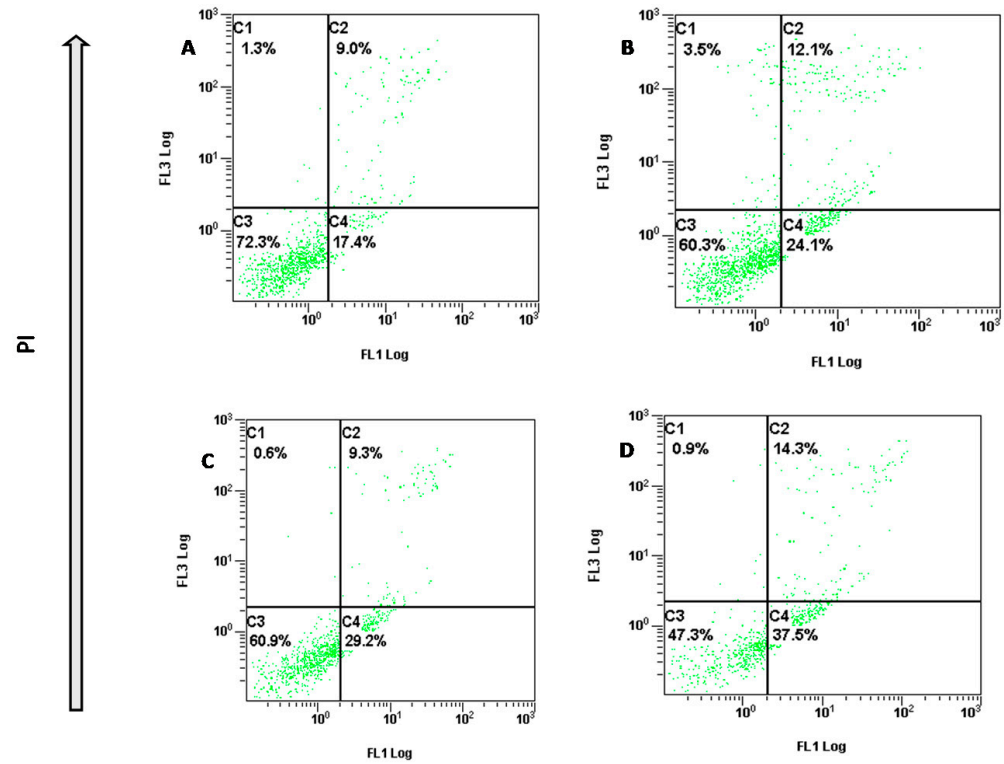

Annexin V/FITC

Figure 2. Histogram showing different phases of staining MCF7 cells with annexin V FITC/PI treated with compound 1 (24 h; A: 0, B: $5 \mu \mathrm{M}, \mathrm{C}: 10 \mu \mathrm{M}$ and D: $20 \mu \mathrm{M})$. X-axis: annexin V, Y-axis: PI. C1: (necrosis-death, PI+/annexin V-); C2: (late apoptosis, PI+/annexin V+); C3: (living cells, $\mathrm{PI}-$ /annexin V-); C4: (early apoptosis, PI-/annexin V+). Experiment was repeated $3 \times(n=3)$.
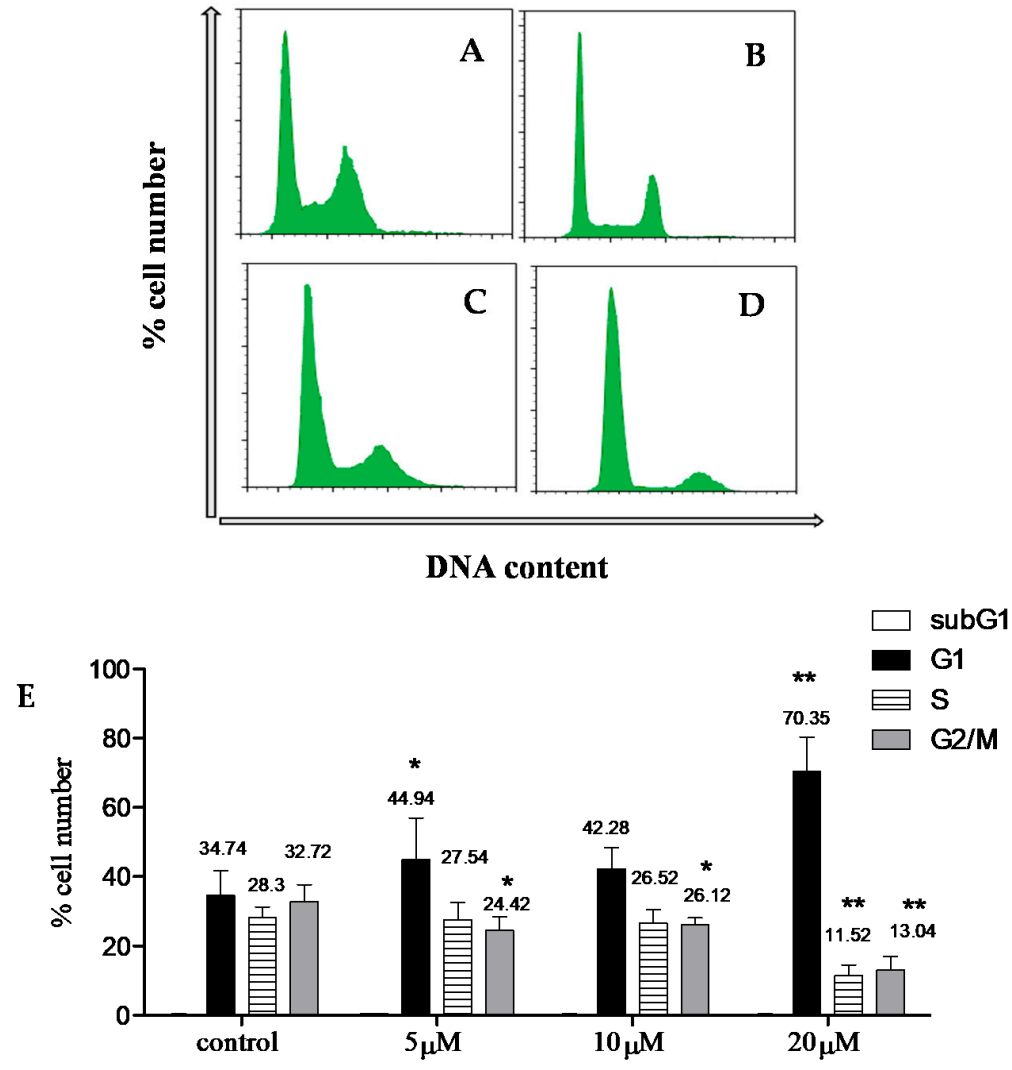

Figure 3. Graphs showing effect of compound 1 (24 h; (A): 0, (B): $5 \mu \mathrm{M}$, (C): $10 \mu \mathrm{M}$, and (D): $20 \mu \mathrm{M})$ in MCF 7 cell cycle distribution. (E): Data shown are mean $\% \pm \operatorname{SD}(n=2)$. Experiment was repeated $3 \times(n=3)$. Statistical differences compared to untreated control cells were assessed by one-way ANOVA with the Tukey's post-hoc multiple comparison test. $p<0.1\left(^{*}\right)$ and $p<0.01\left({ }^{* *}\right)$ were taken as significant. 


\section{Materials and Methods}

\subsection{General Experimental Procedure}

UV spectra were collected with a Shimadzu UV-1650PC spectrophotometer; IR spectra were measured on a Shimadzu Infrared-400 spectrophotometer (Shimadzu, Kyoto, Japan). The ${ }^{1} \mathrm{H}$ - and ${ }^{13} \mathrm{C}$ - or ${ }^{13} \mathrm{C}$-APT NMR measurements were obtained with BrukerAvance III spectrometer operating at 500 or $400 \mathrm{MHz}\left(\right.$ for $\left.{ }^{1} \mathrm{H}\right)$ and 125 or $100 \mathrm{MHz}\left(\right.$ for ${ }^{13} \mathrm{C}$ ) in DMSO- $d_{6}$ solution, and chemical shifts were expressed in $\delta(\mathrm{ppm})$ with reference to TMS and coupling constant $(J)$ in Hertz. ${ }^{13} \mathrm{C}$ multiplicities were determined by the DEPT pulse sequence $\left(135^{\circ}\right)$ or APT experiment. HSQC and HMBC NMR experiments were carried out using Bruker AV-500 spectrometer. EIMS was carried on Scan EIMS-TIC, VG-ZAB-HF, X-mass $(158.64,800.00)$ mass spectrometer (VG Analytical, Inc., Palo Alto, CA, USA). Silica gel (Si gel 60, Merck, Kenilworth, NJ, USA) and sephadex LH-20 (Pharmacia, New Jersey, NJ, USA) were used for the open column chromatography. Solid phase extraction was performed on $\mathrm{SPE}_{\mathrm{C}} \mathrm{C}_{18}$ cartridges (strata columns). Semi-prep HPLC was performed on Waters semi-prep HPLC (Waters, Milford, MA, USA), ODS column (Waters XBridge C-18, $5 \mu \mathrm{m}, 10 \times 150 \mathrm{~mm}$ Prep column); detector: PDA at $210-400 \mathrm{~nm}$; flow rate: $2.0 \mathrm{~mL} / \mathrm{min}$, sample volume (loop): $100 \mathrm{~mL}$. The entire system was controlled using Empower 3 Software. TLC was carried out on precoated silica gel 60 F254 (Merck) plates. Developed chromatograms were visualized by spraying with $1 \%$ vanillin $-\mathrm{H}_{2} \mathrm{SO}_{4}$, followed by heating at $100{ }^{\circ} \mathrm{C}$ for $5 \mathrm{~min}$ and by exposure to the vapors of a concentrated ammonia solution (25\%).

\subsection{Plant Material}

The roots of Rhamnus disperma Ehrenb were collected from Saint Kathrin Protectorate, South Sinai, Egypt in April 2013, and were kindly identified by Dr. Ibraheem El-Garf, Professor of Plant Taxonomy, Faculty of Science, Cairo University, Egypt. A voucher specimen $\{$ RD2013 $\}$ was deposited in the Pharmacognosy Department, Faculty of Pharmacy, Al-Azhar University, Cairo, Egypt. The collected roots were sliced into small pieces and subjected to shade drying at room temperature.

\subsection{Extraction and Isolation}

The air-dried powdered roots of $R$. disperma $(700 \mathrm{~g})$ were exhaustively extracted with ethyl alcohol $(3 \times 4 \mathrm{~L})$. The total alcoholic extracts were combined and concentrated under vacuum to dryness at $40^{\circ} \mathrm{C}$ which resulted in $145 \mathrm{~g}$ of the dried extract. The dried extract was suspended in $500 \mathrm{~mL}$ distilled water and defatted with petroleum ether. The defatted aqueous extract was partitioned with ethyl acetate (EtOAc) to give about $20 \mathrm{~g}$ of the ethyl acetate fraction. The remaining aqueous extract was partitioned with $n$-butanol to give about $40 \mathrm{~g}$ of the $n$-butanol fraction. The ethyl acetate fraction was applied to a column of Si gel and eluted with $n$-hexane-EtOAc (90:10 $\rightarrow 0: 100)$ to give seven fractions of A to G. Fraction A $(960 \mathrm{mg}$ ) was rechromatographed on a column of Si gel and eluted with chloroform to give four subfractions of A1 to A4. HPLC analysis of subfraction A3 (400 mg) showed three major peaks (Figure 4) which was separated by repeated semi-preparative HPLC on the ODS column. The solvent system used is a gradient starting at $30 \%$ methanol in $2 \%$ formic acid which was held for $5 \mathrm{~min}$, followed by the gradual increase to $100 \%$ methanol after $25 \mathrm{~min}$ to give compound $\mathbf{1}(40 \mathrm{mg})$, compound $\mathbf{2}(30 \mathrm{mg})$ andcompound 3 (45 mg) with retention times 19.98, 20.41, and $20.53 \mathrm{~min}$, respectively. Fraction F (950 mg) was subjected to Si gel column eluted with chloroform-methanol (100:0 $\rightarrow 80: 20)$ to give three sub-fractions; F1 to F3. Subfraction F2 (300 mg) was rechromatographed over Si gel column using chloroform-methanol (100:0 $\rightarrow 90: 10)$ to give two further subfractions of F2a and F2b. Subfraction F2a (90 mg) was purified by Sephadex LH-20 column (MeOH) to give compound $4(8 \mathrm{mg})$. The subfraction $\mathrm{F} 2 \mathrm{~b}(110 \mathrm{mg})$ was subjected to $\mathrm{Si}$ gel $\mathrm{C}_{18}$ column chromatography eluted with water-methanol $(100.0 \rightarrow 30: 70)$ to give compound $\mathbf{5}(10 \mathrm{mg})$ and compound $\mathbf{6}(11 \mathrm{mg})$. Fraction $\mathrm{G}(800 \mathrm{mg})$ was further applied to a column of Si gel and eluted with chloroform-methanol (95:5 $\rightarrow 70: 30)$ to give two subfractions of G1 and G2. Subfraction G1 ( $390 \mathrm{mg}$ ) was subjected to an SPE- $\mathrm{C}_{18}$ cartridge eluted with $\mathrm{H}_{2} \mathrm{O}-\mathrm{CH}_{3} \mathrm{OH}$ 
$(100: 0 \rightarrow 50: 50)$ to give three fractions of G1a, G1b and G1c. Fraction G1b (70 mg) was rechromatographed over Si gel column eluted with chloroform-methanol (90:10) followed by a column of Sephadex LH-20 (MeOH) to give compound $8(12 \mathrm{mg})$. Subfraction G2 (220 mg) was subjected to an $S P E-\mathrm{C}_{18}$ cartridge eluted with $\mathrm{H}_{2} \mathrm{O}-\mathrm{CH}_{3} \mathrm{OH}(20: 10 \rightarrow 50: 50)$ to give two fractions of G2a and G2b. Fraction G2a (90 mg) was rechromatographed over Si gel column eluted with chloroform-methanol (80:20) followed by a column of Sephadex LH-20 $(\mathrm{MeOH})$ to give compound $7(18 \mathrm{mg})$ (the isolation scheme is provided in the Supplementary Materials).

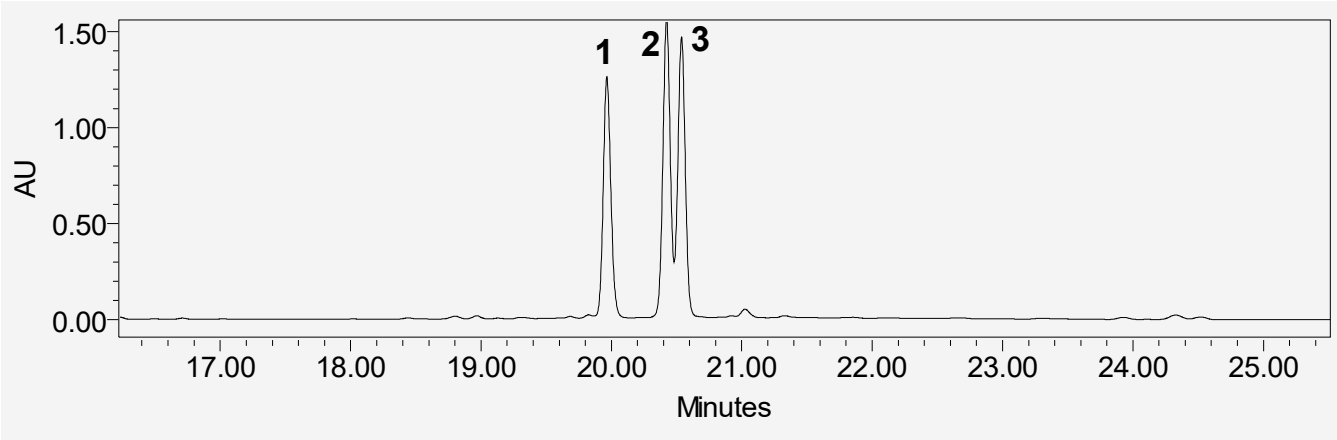

Figure 4. HPLC chromatogram of fraction A. Peaks 1, 2, and 3 referred to compound 1, 2, and 3, respectively.

\subsection{Spectroscopic Analysis of the Isolated Compounds}

Spectra are provided in the Supplementary Materials.

5,4'-dihydroxy-3,6,7-tri-O-methyl flavone (penduletin) (1): Yellow crystals [MeOH]; UV $\lambda_{\max }(\mathrm{MeOH}) \mathrm{nm}: 257 \mathrm{sh}, 276,340, \mathrm{IR} v_{\max }(\mathrm{KBr}) \mathrm{cm}^{-1}: 3380,2923,1660,1610,1463$, 1193; ${ }^{1} \mathrm{H}$ NMR (DMSO- $\left.d_{6}, 500 \mathrm{MHz}\right) \delta 12.63$ (1H, brs, 5-OH), 7.99 (1H, d, J = $7.5 \mathrm{~Hz}, \mathrm{H}-2^{\prime}$, H-6') $6.97\left(1 \mathrm{H}, \mathrm{d}, J=7.5 \mathrm{~Hz}, \mathrm{H}-3^{\prime}, \mathrm{H}-5^{\prime}\right), 6.89$ (s, H-8), $3.92\left(3 \mathrm{H}, \mathrm{s}, 7-\mathrm{OCH}_{3}\right), 3.80(3 \mathrm{H}, \mathrm{s}$, 3- $\left.\mathrm{OCH}_{3}\right), 3.74\left(3 \mathrm{H}, \mathrm{s}, 6-\mathrm{OCH}_{3}\right) ;{ }^{13} \mathrm{C}$ NMR (DMSO- $\left.d_{6}, 125 \mathrm{MHz}\right) \delta 178.7(\mathrm{C}-4), 160.9\left(\mathrm{C}-4^{\prime}\right)$, 159.1 (C-7), 156.5 (C-2), 152.3 (C-9), 152.2 (C-5), 138.1 (C-3), 132.1 (C-6), 130.7 (C-2', C-6'), $120.9\left(\mathrm{C}-1^{\prime}\right), 116.2\left(\mathrm{C}-3^{\prime}, \mathrm{C}^{-5}{ }^{\prime}\right), 106.1(\mathrm{C}-10), 91.9(\mathrm{C}-8), 60.5\left(6-\mathrm{OCH}_{3}\right), 60.2\left(3-\mathrm{OCH}_{3}\right), 57.0$ $\left(7-\mathrm{OCH}_{3}\right)$; EIMS m/z $344[\mathrm{M}]^{+}, 343[\mathrm{M}-1]^{+}, 329[\mathrm{M}-15]^{+}$.

5,3'-dihydroxy-3,6,7,4', $5^{\prime}$-penta-O-methyl flavone (2): Yellow crystals [MeOH]; UV $\lambda_{\max }(\mathrm{MeOH}) \mathrm{nm}: 255 \mathrm{sh}, 273,334, \mathrm{IR} v_{\max }(\mathrm{KBr}) \mathrm{cm}^{-1}: 3385,2920,1655,1615,1462,1190$; ${ }^{1} \mathrm{H}$ NMR (DMSO- $\left.d_{6}, 500 \mathrm{MHz}\right) \delta 12.49$ (1H, brs, 5-OH), 9.70 (1H, brs, 3'-OH), 7.27 (1H, s, H-2') $7.19\left(1 \mathrm{H}, \mathrm{s}, \mathrm{H}-6^{\prime}\right), 6.83(\mathrm{~s}, \mathrm{H}-8), 3.90\left(3 \mathrm{H}, \mathrm{s}, 7-\mathrm{OCH}_{3}\right), 3.85\left(3 \mathrm{H}, \mathrm{s}, 5^{\prime}-\mathrm{OCH}_{3}\right), 3.80(3 \mathrm{H}, \mathrm{s}$, $\left.3-\mathrm{OCH}_{3}\right), 3.77\left(3 \mathrm{H}, \mathrm{s}, 4^{\prime}-\mathrm{OCH}_{3}\right), 3.72\left(3 \mathrm{H}, \mathrm{s}, 6-\mathrm{OCH}_{3}\right) ;{ }^{13} \mathrm{C} \mathrm{NMR}\left(\mathrm{DMSO}-d_{6}, 125 \mathrm{MHz}\right)$ $\delta 178.82$ (C-4), 159.3 (C-7), 155.8 (C-2), 153.5 (C-5'), 152.3 (C-9), 152.0 (C-5), 151.0 (C-3'), 139.5 (C-4'), 138.9 (C-3), 132.1 (C-6), 125.4 (C-1'), 110.4 (C-2'), 106.1 (C-10), 104.4 (C-6'), $91.9(\mathrm{C}-8), 60.6\left(6-\mathrm{OCH}_{3}\right.$ and $\left.4^{\prime}-\mathrm{OCH}_{3}\right), 60.4\left(3-\mathrm{OCH}_{3}\right), 56.9\left(7-\mathrm{OCH}_{3}\right), 56.5\left(5^{\prime}-\mathrm{OCH}_{3}\right)$; EIMS m/z $404[\mathrm{M}]^{+}, 403[\mathrm{M}-1]^{+}, 389[\mathrm{M}-15]^{+}$.

5-hydroxy-3,6,7,3', $4^{\prime}, 5^{\prime}$-hexa-O-methyl flavone (3): Pale-yellow amorphous powder $[\mathrm{MeOH}] ; \mathrm{UV} \lambda_{\max }(\mathrm{MeOH}) \mathrm{nm}: 265 \mathrm{sh}, 274,280 \mathrm{sh}, 334, \mathrm{IR} v_{\max }(\mathrm{KBr}) \mathrm{cm}^{-1}$ : 3388, 2923, 1652, 1613, 1462, 1192; ${ }^{1} \mathrm{H}$ NMR (DMSO- $\left.d_{6}, 500 \mathrm{MHz}\right) \delta 12.51$ (1H, brs, 5-OH), 7.39 (2H, s, H-2', H-6'), 6.93 (s, H-8), $3.92\left(3 \mathrm{H}, \mathrm{s}, 7-\mathrm{OCH}_{3}\right), 3.88\left(6 \mathrm{H}, \mathrm{s}, 3^{\prime}-\mathrm{OCH}_{3}, 5^{\prime}-\mathrm{OCH}_{3}\right), 3.84(3 \mathrm{H}$, $\left.\mathrm{s}, 3-\mathrm{OCH}_{3}\right), 3.77\left(3 \mathrm{H}, \mathrm{s}, 4^{\prime}-\mathrm{OCH}_{3}\right), 3.73\left(3 \mathrm{H}, \mathrm{s}, 6-\mathrm{OCH}_{3}\right) ;{ }^{13} \mathrm{C}$ NMR $\left(\mathrm{DMSO}-d_{6}, 125 \mathrm{MHz}\right)$ б 178.8 (C-4), 159.3 (C-7), 156.0 (C-2), 153.3 (C-3', C-5'), 152.0 (C-5), 152.3 (C-9), 140.5 (C-4'), 139.0 (C-3), 132.1 (C-6), $125.5\left(\mathrm{C}-1^{\prime}\right), 106.4\left(\mathrm{C}-2^{\prime}, \mathrm{C}-6^{\prime}\right), 106.2$ (C-10), 92.1 (C-8), 60.7 $\left(4^{\prime}-\mathrm{OCH}_{3}\right), 60.5\left(6-\mathrm{OCH}_{3}\right), 60.4\left(3-\mathrm{OCH}_{3}\right), 57.0\left(7-\mathrm{OCH}_{3}\right), 56.9\left(3^{\prime}, 5^{\prime}-\mathrm{OCH}_{3}\right) ; \mathrm{EIMS} m / z 418$ $[\mathrm{M}]^{+}, 417[\mathrm{M}-1]^{+}, 403[\mathrm{M}-15]^{+}$.

kampferol 7-O- $\alpha$-L-rhamnopyranoside (4): Yellow amorphous powder [MeOH]; UV $\lambda_{\max }(\mathrm{MeOH}) \mathrm{nm}: 246 \mathrm{sh}, 267,315 \mathrm{sh}, 351$; IR $v_{\max }(\mathrm{KBr}) \mathrm{cm}^{-1}$ : 3440, 1655, 1600, 1515; ${ }^{1} \mathrm{H}$ NMR (DMSO- $\left.d_{6}, 400 \mathrm{MHz}\right)$ aglycone $\delta 8.10\left(2 \mathrm{H}, \mathrm{d}, J=8.5 \mathrm{~Hz}, \mathrm{H}-2^{\prime}, \mathrm{H}-6{ }^{\prime}\right), 6.93(2 \mathrm{H}$, $\left.\mathrm{d}, J=8.8 \mathrm{~Hz}, \mathrm{H}-3^{\prime}, \mathrm{H}-5^{\prime}\right), 6.82(1 \mathrm{H}, \mathrm{d}, J=1.8 \mathrm{~Hz}, \mathrm{H}-8), 6.41(1 \mathrm{H}, \mathrm{d}, J=1.8 \mathrm{~Hz}, \mathrm{H}-6)$; sugar 
moiety $\delta 5.54\left(1 \mathrm{H}, \mathrm{s}, \mathrm{H}-1^{\prime \prime}\right), 3.66-3.29\left(4 \mathrm{H}, \mathrm{m}, \mathrm{H}-2^{\prime \prime}-\mathrm{H}-5^{\prime \prime}\right), 1.11\left(3 \mathrm{H}, \mathrm{d}, J=6.6 \mathrm{~Hz}, \mathrm{H}-6^{\prime \prime}\right)$; EIMS $m / z 286$ [M-rhamnosyl] ${ }^{+}$.

Isorhamnetin 3-O- $\beta$-D-glucopyranoside (5): Yellow amorphous powder (MeOH); UV $\lambda_{\max }(\mathrm{MeOH}) \mathrm{nm}: 254,266 \mathrm{sh}, 355 ; \mathrm{IR} v_{\max }(\mathrm{KBr}) \mathrm{cm}^{-1}: 3365,2925,1660,1615,1490$, 1190; ${ }^{1} \mathrm{H}-\mathrm{NMR}\left(\mathrm{DMSO}-d_{6}, 400 \mathrm{MHz}\right)$ aglycone $\delta 12.65(1 \mathrm{H}, \mathrm{s}, \mathrm{OH}-5), 7.94\left(1 \mathrm{H}, \mathrm{s}, \mathrm{H}-2^{\prime}\right)$, $7.50\left(1 \mathrm{H}, \mathrm{d}, J=8.4 \mathrm{~Hz}, \mathrm{H}-6^{\prime}\right), 6.92\left(1 \mathrm{H}, \mathrm{d}, J=8.3 \mathrm{~Hz}, \mathrm{H}-5^{\prime}\right), 6.43(1 \mathrm{H}, \mathrm{s}, \mathrm{H}-8), 6.20(1 \mathrm{H}$, $\mathrm{s}, \mathrm{H}-6), 3.84\left(3 \mathrm{H}, \mathrm{s}, 3^{\prime}-\mathrm{OCH}_{3}\right)$; sugar moiety $\delta 5.57\left(1 \mathrm{H}, \mathrm{d}, J=7.2 \mathrm{~Hz}, \mathrm{H}-1^{\prime \prime}\right), 3.65-3.12$ $\left(5 \mathrm{H}, \mathrm{m}, \mathrm{H}-2^{\prime \prime}-\mathrm{H}_{2}-6^{\prime \prime}\right) ;{ }^{13} \mathrm{C}-\mathrm{APT}$ NMR (DMSO- $\left.d_{6}, 100 \mathrm{MHz}\right)$ aglycone $\delta 177.8(\mathrm{C}, \mathrm{C}-4), 165.0$ (C, C-7), 161.7 (C, C-5), 156.9 (C, C-2), 156.7 (C, C-9), 149.9 (C, C-3'), 147.4 (C, C-4'), 133.4 (C, C-3), 122.5 (CH, C-6'), 121.6 (C, C-1'), 115.7 (CH, C-5'), 113.9 (C, C-2'), 104.4 (C, C-10), $99.3(\mathrm{CH}, \mathrm{C}-6), 94.2(\mathrm{CH}, \mathrm{C}-8), 56.1\left(\mathrm{CH}_{3}, 3^{\prime}-\mathrm{OCH}_{3}\right)$; sugar moiety $\delta 101.3\left(\mathrm{CH}, \mathrm{C}-1^{\prime \prime}\right), 77.9$ $\left(\mathrm{CH}, \mathrm{C}-3^{\prime \prime}\right), 76.9\left(\mathrm{CH}, \mathrm{C}-5^{\prime \prime}\right), 74.8\left(\mathrm{CH}, \mathrm{C}-2^{\prime \prime}\right), 70.3\left(\mathrm{CH}, \mathrm{C}-4^{\prime \prime}\right), 61.1\left(\mathrm{CH}_{2}, \mathrm{C}-6^{\prime \prime}\right) ; \mathrm{EIMS} m / z$

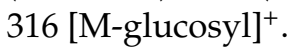

Quercetin 7-O- $\alpha$-L-rhamnopyranoside (6): Yellow amorphous powder [MeOH]; UV $\lambda_{\max }(\mathrm{MeOH}) \mathrm{nm}: 255,268 \mathrm{sh}, 374 ; \mathrm{IR} v_{\max }(\mathrm{KBr}) \mathrm{cm}^{-1}: 3450,1655,1650,1590 ;{ }^{1} \mathrm{H}$ NMR (DMSO- $\left.d_{6}, 400 \mathrm{MHz}\right)$ aglycone $\delta 12.67(1 \mathrm{H}, \mathrm{s}, \mathrm{OH}-5), 7.72\left(1 \mathrm{H}, \mathrm{d}, J=2.0 \mathrm{~Hz}, \mathrm{H}-2^{\prime}\right), 7.59$ $\left(1 \mathrm{H}, \mathrm{dd}, J=8.3,1.5 \mathrm{~Hz}, \mathrm{H}-6^{\prime}\right), 6.89\left(1 \mathrm{H}, \mathrm{d}, J=8.7 \mathrm{~Hz}, \mathrm{H}-5^{\prime}\right), 6.79(1 \mathrm{H}, \mathrm{d}, J=1.8 \mathrm{~Hz}, \mathrm{H}-8), 6.41$ $(1 \mathrm{H}, \mathrm{d}, J=1.9 \mathrm{~Hz}, \mathrm{H}-6)$, sugar moiety $\delta 5.55\left(1 \mathrm{H}, \mathrm{s}, \mathrm{H}-1^{\prime \prime}\right), 3.66-3.12\left(4 \mathrm{H}, \mathrm{m}, \mathrm{H}-2^{\prime \prime}-\mathrm{H}-5^{\prime \prime}\right)$, $1.13\left(3 \mathrm{H}, \mathrm{d}, J=6.1 \mathrm{~Hz}, \mathrm{H}-6^{\prime \prime}\right)$; EIMS m/z 302 [M-rhamnosyl] $]^{+}$.

Kampferol 3,7-di-O- $\alpha$-L-rhamnopyranoside (7): Yellow amorphous powder $[\mathrm{MeOH}]$; UV $\lambda_{\max }(\mathrm{MeOH}) \mathrm{nm}: 244 \mathrm{sh}, 266,315 \mathrm{sh}, 350 ; \mathrm{IR} v_{\max }(\mathrm{KBr}) \mathrm{cm}^{-1}$ : 3445, 1660, 1610, 1515; ${ }^{1} \mathrm{H}$ NMR (DMSO- $\left.d_{6}, 400 \mathrm{MHz}\right)$ aglycone $\delta 12.59(1 \mathrm{H}, \mathrm{s}, \mathrm{OH}-5), 7.79(2 \mathrm{H}, \mathrm{d}, J=8.7 \mathrm{~Hz}, \mathrm{H}-2$ ', H-6'), $6.92\left(2 \mathrm{H}, \mathrm{d}, J=8.7 \mathrm{~Hz}, \mathrm{H}-3^{\prime}, \mathrm{H}-5^{\prime}\right), 6.78(1 \mathrm{H}, \mathrm{d}, J=2.0 \mathrm{~Hz}, \mathrm{H}-8), 6.45(1 \mathrm{H}, \mathrm{d}, J=2.0 \mathrm{~Hz}$, H-6); sugar moieties $\delta 5.55\left(1 \mathrm{H}, \mathrm{d}, J=1.8 \mathrm{~Hz}, \mathrm{H}-1^{\prime \prime}\right), 5.30\left(1 \mathrm{H}, \mathrm{d}, J=1.4 \mathrm{~Hz}, \mathrm{H}-1^{\prime \prime}\right)$, 3.66-3.14 $\left(8 \mathrm{H}, \mathrm{m}, \mathrm{H}-2^{\prime \prime}, \mathrm{H}-2^{\prime \prime \prime}-\mathrm{H}-5^{\prime \prime}, \mathrm{H}-5^{\prime \prime \prime}\right), 1.14\left(3 \mathrm{H}, \mathrm{d}, J=6.1 \mathrm{~Hz}, \mathrm{H}-6^{\prime \prime}\right), 0.81(3 \mathrm{H}, \mathrm{d}, \mathrm{J}=5.5 \mathrm{~Hz}$, H-6"' $) ;{ }^{13} \mathrm{C}$-APT NMR (DMSO-d $d_{6}, 100 \mathrm{MHz}$ ) aglycone $\delta 178.4$ (C, C-4), 162.2 (C, C-7), 161.4 (C, C-5), 160.6 (C, C-4'), 158.3 (C, C-2), 156.6 (C, C-9), 135.0 (C, C-3), 131.2 (CH, C-2', 6'), 120.8, (C, C-1'), 115.9 (CH, C-3', 5'), 106.2 (C, C-10), 99.9 (CH, C-6), 95.0 (CH, C-8); sugar moieties $\delta 102.3\left(\mathrm{CH}, \mathrm{C}-1^{\prime \prime}\right), 98.9\left(\mathrm{CH}, \mathrm{C}-1^{\prime \prime \prime}\right), 72.1,\left(\mathrm{CH}, \mathrm{C}-4^{\prime \prime}\right), 71.6\left(\mathrm{CH}, \mathrm{C}-4^{\prime \prime \prime}\right), 71.1(\mathrm{CH}$, C-2"'), $70.8\left(\mathrm{CH}, \mathrm{C}-2^{\prime \prime \prime}\right), 70.7\left(\mathrm{CH}, \mathrm{C}-3^{\prime \prime}\right), 70.5\left(\mathrm{CH}, \mathrm{C}-5^{\prime \prime}, \mathrm{C}-3^{\prime \prime \prime}\right), 70.3\left(\mathrm{CH}, \mathrm{C}-5^{\prime \prime \prime}\right), 18.4\left(\mathrm{CH}_{3}\right.$,

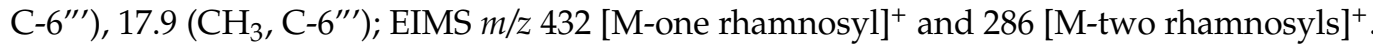

Benzyl-O- $\beta$-D-glucopyranoside (8): Colorless oil; UV $\lambda_{\max }(\mathrm{MeOH}) \mathrm{nm}$ : 257 , IRv $v_{\max }$ $(\mathrm{KBr}) \mathrm{cm}^{-1}: 3430(\mathrm{OH}), 2922(\mathrm{CH}), 1650,1595$ (aromatic); ${ }^{1} \mathrm{H}$ NMR (DMSO-d $\left.d_{6}, 400 \mathrm{MHz}\right)$ aglycone $\delta 7.40(2 \mathrm{H}, \mathrm{d}, J=6.9 \mathrm{~Hz}, \mathrm{H}-2, \mathrm{H}-6), 7.34(2 \mathrm{H}, \mathrm{t}, J=7.0 \mathrm{~Hz}, \mathrm{H}-3, \mathrm{H}-5), 7.29(1 \mathrm{H}, \mathrm{m}$, H-4), $4.83(1 \mathrm{H}, \mathrm{d}, J=12.2 \mathrm{~Hz}, \mathrm{H}-7 \mathrm{a}), 4.58(1 \mathrm{H}, \mathrm{d}, J=12.2 \mathrm{~Hz}, \mathrm{H}-7 \mathrm{~b})$; sugar moiety $\delta 4.24(1 \mathrm{H}$, d, J= 7.6 Hz, H-1'), $3.71\left(1 \mathrm{H}, \mathrm{d}, J=11.9 \mathrm{~Hz}, \mathrm{H}-6^{\prime} \mathrm{a}\right), 3.47$ (1H, m, H-6'b), 3.43-3.05 (4H, m, H-2'-H-5'); ${ }^{13} \mathrm{C}$ NMR(DMSO- $\left.d_{6}, 100 \mathrm{MHz}\right)$ aglycone $\delta 138.5(\mathrm{C}, \mathrm{C}-1), 128.6(\mathrm{CH}, \mathrm{C}-3, \mathrm{C}-5)$, $128.1(\mathrm{CH}, \mathrm{C}-2, \mathrm{C}-6), 127.8(\mathrm{CH}, \mathrm{C}-4)$; sugar moiety $\delta 102.5\left(\mathrm{CH}, \mathrm{C}-1^{\prime}\right), 77.4\left(\mathrm{CH}, \mathrm{C}-5^{\prime}\right), 77.2$ $\left(\mathrm{CH}, \mathrm{C}-3^{\prime}\right), 74.0\left(\mathrm{CH}, \mathrm{C}-2^{\prime}\right), 70.6\left(\mathrm{CH}, \mathrm{C}-4^{\prime}\right), 70.0\left(\mathrm{CH}_{2}, \mathrm{C}-7\right), 61.7\left(\mathrm{CH}_{2}, \mathrm{C}-6^{\prime}\right)$; EIMS m/z 108

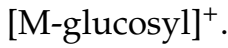

\subsection{Acetylation of Compound 3}

Accurately, $30 \mathrm{mg}$ of compound 3 was heated at $130{ }^{\circ} \mathrm{C}$ for $4 \mathrm{~h}$ with $2.0 \mathrm{~mL}$ of Ac,O according to the method described in Neves et al. [26]. The mixture was poured into ice-water, the precipitate was filtered off, and the acetylated compound was purified on silica gel CC with $\mathrm{CH}_{2} \mathrm{Cl}_{2}$-EtOAc (40:1) to give compound 9 (12 mg).

5-O-acetyl-3,6,7,3', $4^{\prime}, 5^{\prime}$-hexa-O-methyl flavone (9): Pale-yellow amorphous powder $[\mathrm{MeOH}] ;{ }^{1} \mathrm{H}$ NMR (DMSO-d 6 , $\left.500 \mathrm{MHz}\right) \delta 7.38$ (3H, s, H-8, H-2', H-6'), $4.00\left(3 \mathrm{H}, \mathrm{s}, 7-\mathrm{OCH}_{3}\right)$, $3.89\left(6 \mathrm{H}, \mathrm{s}, 3^{\prime}-\mathrm{OCH}_{3}, 5^{\prime}-\mathrm{OCH}_{3}\right), 3.77\left(6 \mathrm{H}, \mathrm{s}, 3-\mathrm{OCH}_{3}, 4^{\prime}-\mathrm{OCH}_{3}\right), 3.74\left(3 \mathrm{H}, \mathrm{s}, 6-\mathrm{OCH}_{3}\right)$, acetyl $\delta 2.39\left(3 \mathrm{H}, \mathrm{s}, \mathrm{CH}_{3}\right) ;{ }^{13} \mathrm{C}$ NMR (DMSO-d $\left.6,125 \mathrm{MHz}\right) \delta 172.6(\mathrm{C}-4), 157.9$ (C-7), 153.7 (C-2), 153.7 (C-3', C-5'), 153.0 (C-5), 140.2 (C-9), 141.2 (C-3), 140.8 (C-4'), 139.2 (C-6), 125.7 (C-1'), $106.3\left(\mathrm{C}-2^{\prime}, \mathrm{C}-6^{\prime}\right), 111.1(\mathrm{C}-10), 99.6(\mathrm{C}-8), 61.5\left(6-\mathrm{OCH}_{3}\right), 60.7\left(4^{\prime}-\mathrm{OCH}_{3}\right), 60.2\left(3-\mathrm{OCH}_{3}\right)$ $57.3\left(7-\mathrm{OCH}_{3}\right), 56.6\left(3^{\prime}, 5^{\prime}-\mathrm{OCH}_{3}\right)$, acetyl $\delta 169.4(\mathrm{CO}), 21,2\left(\mathrm{CH}_{3}\right) ; \mathrm{EIMS} \mathrm{m} / z 460[\mathrm{M}]^{+}$. 


\subsection{Acid Hydrolysis of Compounds 4-8}

$5 \mathrm{mg}$ of each compound was separately refluxed with $2 \mathrm{M} \mathrm{HCl}$ in $\mathrm{MeOH}(5 \mathrm{~mL})$ at $80^{\circ} \mathrm{C}$ for $4 \mathrm{~h}$ in a water bath. The reaction mixture was evaporated, and the hydrolysate after dilution with $\mathrm{H}_{2} \mathrm{O}(10 \mathrm{~mL})$ was extracted with $\mathrm{CHCl}_{3}(3 \times 10 \mathrm{~mL})$. The $\mathrm{CHCl}_{3}$ extracts were evaporated to afford the aglycones, which were identified as kampferol for 4 and $\mathbf{7}$, isorhamnetin for $\mathbf{5}$, quercetin for $\mathbf{6}$ and benzyl alcohol for $\mathbf{8}$ by comparison with authentic samples, respectively. The aqueous layer was neutralized with sodium carbonate and concentrated to $1 \mathrm{~mL}$ under reduced pressure. The residue was compared with standard sugars by Si gel TLC $\left[\left(\mathrm{CHCl}_{3}-\mathrm{MeOH}-\mathrm{H}_{2} \mathrm{O}: 30: 12: 4\right), 9 \mathrm{~mL}\right.$ of lower layer and $1 \mathrm{~mL}$ of HOAc], which indicated the sugars to be L-rhamnose in compounds 4,6 and 7 and glucose in compounds 5 and 8.

\subsection{Cytotoxicity Assay}

Three cancerous cell lines, as well as one normal fibroblast cell line, were bought from the ATCC, USA: MCF 7 (human breast adenocarcinoma), A2780 (human ovary adenocarcinoma), HT 29 (human colon adenocarcinoma), and MRC5 (normal human fetal lung fibroblast). The culture procedure was performed as described in the literature [27,28]. Briefly, the cells were sub-cultured at $37^{\circ} \mathrm{C}, 5 \% \mathrm{CO}_{2}, 95 \%$ air, and $100 \%$ relative humidity. RPMI-1640 media (10\% FBS, L-glutamine and 1\% antibiotic-antimycotic) was used for all cells except for MRC5, which was maintained in Eagles minimum essential medium (EMEM, 10\% FBS and 1\% antibiotic-antimycotic). Cytotoxicity of compounds 1-7 and $\mathbf{9}$ was evaluated by an MTT assay as previously described [29]. Each of the three cell lines and one normal fibroblast were cultured in 96-well plates $\left(3 \times 10^{3} /\right.$ well), and incubated at $37^{\circ} \mathrm{C}$ overnight. Final concentrations of each compound were: $0,0.05,0.5,5,25$, and $50 \mu \mathrm{M}$ in media (DMSO 0.1\%). Each concentration was tested in triplicates. The plates were incubated for $72 \mathrm{~h}$ and then MTT $(50 \mu \mathrm{L})$ was added to each well. Plates were incubated for $3 \mathrm{~h}$, supernatant was aspirated, and $100 \mu \mathrm{L}$ of DMSO was added to each well. Absorbance was read on a multi-plate reader. The optical density of the purple formazan A550 is proportional to the number of viable cells. Compound concentrations causing $50 \%$ inhibition $\left(\mathrm{IC}_{50}\right)$ compared to control cell growth $(100 \%)$ were determined. GraphPad Prism version 5.00 for Windows, GraphPad Software (San Diego, CA, USA) was used for analysis.

\subsection{Annexin VFITC/PI Apoptosis Assay}

The Annexin V FITC/PI assay was devised to quantify apoptosis using MCF 7 cells [30]. MCF 7 cells were cultured in 6 well plates $\left(1 \times 10^{5}\right.$ cells/well $)$ in $2 \mathrm{~mL}$ medium overnight at $37^{\circ} \mathrm{C}$. Then it was treated by compound 1 ( $24 \mathrm{~h}$; final concentrations: $0,5,10$, and $20 \mu \mathrm{M}$ ). Media was collected in tubes and kept on ice, and remaining cells were trypsinized, incubated at $37^{\circ} \mathrm{C}$ and added to previous tubes. Cells were centrifuged $(350 \mathrm{~g})$ and supernatants were discarded. Cells were washed with PBS, centrifuged and pellets re-suspended in binding buffer $(100 \mu \mathrm{L})$ and annexin V FITC $(10 \mu \mathrm{L})$. Tubes were incubated at room temperature in the dark for $20 \mathrm{~min}$. Binding buffer $(400 \mu \mathrm{L})$ and $10 \mu \mathrm{L}$ propidium iodide (PI) were added. Samples were analyzed by flow cytometry (BC FC500) within $1 \mathrm{~h}$. Viable cells were differentiated from early and late apoptotic/necrotic cells by annexin $\mathrm{V}$ (X axis) and PI staining ( $\mathrm{Y}$ axis).

\subsection{Cell Cycle Analysis}

Cell cycle analysis was performed using MCF 7 cells, which were cultured in 6 well plates $\left(1 \times 10^{5}\right.$ cells/well in $2 \mathrm{~mL}$ medium), before treatment with compound $1(0,5$, 10, and $20 \mu \mathrm{M} ; 24 \mathrm{~h}$ ). Cells were washed with cold PBS and trypsinized. Collected cells were centrifuged at $350 \mathrm{~g} / 5 \mathrm{~min}$, and supernatant discarded. Pellets were washed in cold PBS, centrifuged, and fixed overnight in $70 \%$ ice-cold ethanol. Centrifuged cells were re-suspended in cold PBS with the addition of ribonuclease A (15 min), followed by PI $(2 \mu \mathrm{L} / \mathrm{mL})$. Samples were held on ice and analyzed by flow cytometry. Data analysis of 
the DNA contents (PI bound to DNA) of 20,000 events was carried out using Expo 32 software [31].

\subsection{Statistical Analysis}

Samples were tested in triplicate, and each assay was repeated three times. Data were expressed as mean and standard deviation (mean $\pm \mathrm{SD}$ ). Comparisons were performed using GraphPad Prism version 5.00 for Windows.

\section{Conclusions}

In this study, eight compounds 1-8 were isolated from the roots of Rhamnus disperma. Compounds 1, 4, 5, and 8 were isolated for the first time from the plant. Compound 1 exhibited the highest cytotoxic activity against three cancer cell lines: MCF 7, A2780, and HT 29, with $\mathrm{IC}_{50}$ values of $0.53-2.17 \mu \mathrm{M}$ and was $2-9$ folds more selective against tested cancer cell lines compared to the normal fibroblast cells (MRC5). It also doubled MCF 7 apoptotic populations in a dose dependent manner and caused $\mathrm{G}_{1}$ cell cycle arrest. It is concluded that compound $\mathbf{1}$ has cytotoxic, pro-apoptotic, and cell cycle arrest activities, and could have anticancer activity, which should be further tested using in vivo animal models.

Supplementary Materials: The following are available online, Figures S1-S31: NMR spectra of the compounds; Scheme S1: Extraction, fractionation and isolation of chemical constituents of Rhamnus disperma roots.

Author Contributions: Conceptualization, H.A.M. and E.A.R.; methodology, H.A.M., M.F.A.E.-W., U.S., A.E.-S.I.M., A.N.A. and E.A.R.; software, H.A.M. and E.A.R.; validation, H.A.M., M.F.A.E.-W., U.S., A.E.-S.I.M., A.N.A. and E.A.R.; formal analysis, H.A.M. and U.S.; investigation, H.A.M., M.F.A.E.-W., U.S., A.E.-S.I.M., A.N.A. and E.A.R.; resources, H.A.M., M.F.A.E.-W., U.S., A.E.-S.I.M., A.N.A. and E.A.R.; data curation, H.A.M., A.E.-S.I.M. and E.A.R.; writing-original draft preparation, H.A.M., M.F.A.E.-W., U.S., A.E.-S.I.M., A.N.A. and E.A.R.; writing-review and editing, H.A.M., M.F.A.E.-W., U.S., A.E.-S.I.M., A.N.A. and E.A.R.; funding acquisition, H.A.M. All authors have read and agreed to the published version of the manuscript.

Funding: This research was funded by the Deputyship for Research \& Innovation, Ministry of Education, Saudi Arabia [grant number (QU-IF-1-2-2)].

Institutional Review Board Statement: The study did not involve humans or animals.

Informed Consent Statement: Not applicable.

Data Availability Statement: All data are available in the manuscript and Supplementary File.

Acknowledgments: The authors extend their appreciation to the Deputyship for Research \& Innovation, Ministry of Education and, Saudi Arabia for funding this research work through the project number (QU-IF-1-2-2). The authors also thank the technical support of Qassim University, Kingdom of Saudi Arabia. The authors also thank the laboratory facilities, including instrumental and infrastructural supports of Al-Azhar University, Cairo, Egypt.

Conflicts of Interest: The authors declare no conflict of interest.

Sample Availability: Samples of the compounds are not available.

\section{References}

1. Boulos, L. Flora of Egypt: With 409 Line Drawings and 94 Colour Photographs; Geraniaceae-Boraginaceae; Al Hadara Publishing: Cairo, Egypt, 2000.

2. Marna, E. Cultivated Plants; Academic Press Publishing: London, UK; New York, NY, USA, 1961.

3. Collenette, S. Wildflowers of Saudi Arabia; National Commission for Wildlife Conservation and Development (NCWCD) Publishing: Riyadh, Saudi Arab, 1999.

4. Tackholm, V. Students' Flora of Egypt; Cairo University Publishing: Cairo, Egypt, 1974.

5. Ragab, E.A. Highly methoxylated flavonoids and the anti-eczematous activity of Rhamnus disperma roots. J. Pharmacogn. Phytochem. 2015, 4, 01-08.

6. Marzouk, M.S.; El-Toumy, S.A.A.; Merfort, I.; Nawwar, M.A.M. Polyphenolic metabolites of Rhamnus disperma. Phytochemistry 1999, 52, 943-946. [CrossRef] 
7. Ammar, R.B.; Bhouri, W.; Sghaier, M.B.; Boubaker, J.; Skandrani, I.; Neffati, A.; Bouhlel, I.; Kilani, S.; Mariotte, A.M.; Chekir-Ghedira, L.; et al. Antioxidant and free radical-scavenging properties of three flavonoids isolated from the leaves of Rhamnus alaternus L. (Rhamnaceae): A structure-activity relationship study. Food Chem. 2009, 116, 258-264. [CrossRef]

8. Benamar, H.; Rarivoson, E.; Tomassini, L.; Frezza, C.; Marouf, A.; Bennaceur, M.; Nicoletti, M. Phytochemical profiles, antioxidant and anti-acetylcholinesterasic activities of the leaf extracts of Rhamnus lycioides subsp. oleoides (L.) Jahand. \& Maire in different solvents. Nat. Prod. Res. 2019, 33, 1456-1462.

9. Chen, G.; Li, X.; Saleri, F.; Guo, M. Analysis of flavonoids in Rhamnus davurica and its antiproliferative activities. Molecules 2016, 21, 1275. [CrossRef]

10. Chen, G.; Wu, J.; Li, N.; Guo, M. Screening for anti-proliferative and anti-inflammatory components from Rhamnus davurica Pall. using bio-affinity ultrafiltration with multiple drug targets. Anal. Bioanal. Chem. 2018, 410, 3587-3595. [CrossRef]

11. Hamed, M.M.; Refahy, L.A.; Abdel-Aziz, M.S. Evaluation of antimicrobial activity of some compounds isolated from Rhamnus cathartica L. Orient J. Chem. 2015, 31, 1133-1140. [CrossRef]

12. Ammar, R.B.; Kilani, S.; Bouhlel, I.; Skandrani, I.; Naffeti, A.; Boubaker, J.; Sghaier, M.B.; Bhouri, W.; Mahmoud, A.; Chekir-Ghedira, L.; et al. Antibacterial and cytotoxic activities of extracts from (Tunisian) Rhamnus alaternus (Rhamnaceae). Ann. Microbiol. 2007, 57, 453-460. [CrossRef]

13. Mohammed, H.A. Antioxidant Flavonol Rhamnosides from Rhamnus disperma Roots. Int. J. Pharm. Phytopharm. Res. 2015, 5, 2249-6084.

14. Harborne, J.B. The Flavonoids-Advances in Research since 1986; Chapman and Hall/CRC Publishing: London, UK, 1994.

15. Gorin, P.A.J.; Mazurek, M. Further studies on the assignment of signals in 13C magnetic resonance spectra of aldoses and derived methyl glycosides. Can. J. Chem. 1975, 53, 1212-1223. [CrossRef]

16. Markham, K.R.; Ternai, B.; Stanley, R.; Geiger, H.; Mabry, T.J. Carbon-13 NMR studies of flavonoids-III: Naturally occurring flavonoid glycosides and their acylated derivatives. Tetrahedron 1978, 34, 1389-1397. [CrossRef]

17. Wang, D.-M.; Pu, W.-J.; Wang, Y.-H.; Zhang, Y.-J.; Wang, S.-S. A new isorhamnetin glycoside and other phenolic compounds from Callianthemum taipaicum. Molecules 2012, 17, 4595-4603. [CrossRef]

18. Wagner, H.; Chari, V.M.; Sonnenbichler, J. ${ }^{13}$ C-NMR-spektren natürlich vorkommender flavonoide. Tetrahedron Lett. 1976, 17, 1799-1802. [CrossRef]

19. Wen, P.; Han, H.; Wang, R.; Wang, N.; Yao, X. C-glycosylfavones and aromatic glycosides from Campylotropis hirtella (Franch.) Schindl. Asian J. Tradit. Med. 2007, 2, 149-153.

20. Mastelić, J.; Jerković, I.; Vinković, M.; Džolić, Z.; Vikić-Topić, D. Synthesis of selected naturally occurring glucosides of volatile compounds. Their chromatographic and spectroscopic properties. Croat. Chem. Acta 2004, 77, 491-500.

21. Ly, T.N.; Yamauchi, R.; Shimoyamada, M.; Kato, K. Isolation and structural elucidation of some glycosides from the rhizomes of smaller galanga (Alpinia officinarum Hance). J. Agric. Food Chem. 2002, 50, 4919-4924. [CrossRef]

22. Sak, K. Cytotoxicity of dietary flavonoids on different human cancer types. Pharmacogn. Rev. 2014, 8, 122-146. [CrossRef]

23. Pan, M.-H.; Chen, W.-J.; Lin-Shiau, S.-Y.; Ho, C.-T.; Lin, J.-K. Tangeretin induces cell-cycle G1 arrest through inhibiting cyclindependent kinases 2 and 4 activities as well as elevating Cdk inhibitors p21 and p27 in human colorectal carcinoma cells. Carcinogenesis 2002, 23, 1677-1684. [CrossRef]

24. Benavente-Garcia, O.; Castillo, J. Update on uses and properties of citrus flavonoids: New findings in anticancer, cardiovascular, and anti-inflammatory activity. J. Agric. Food Chem. 2008, 56, 6185-6205. [CrossRef]

25. Walle, T. Methoxylated flavones, a superior cancer chemopreventive flavonoid subclass? Semin. Cancer Biol. 2007, 17, 354-362. [CrossRef]

26. Neves, A.R.; Correia-da-Silva, M.; Silva, P.; Ribeiro, D.; Sousa, E.; Bousbaa, H.; Pinto, M. Synthesis of new glycosylated flavonoids with inhibitory activity on cell growth. Molecules 2018, 23, 1093. [CrossRef] [PubMed]

27. Mohammed, H.A.; Al-Omar, M.S.; El-Readi, M.Z.; Alhowail, A.H.; Aldubayan, M.A.; Abdellatif, A.A.H. Formulation of Ethyl Cellulose Microparticles Incorporated Pheophytin A Isolated from Suaeda vermiculata for Antioxidant and Cytotoxic Activities. Molecules 2018, 24, 1501. [CrossRef] [PubMed]

28. Mohammed, H.A.; Khan, R.A.; Abdel-Hafez, A.A.; Abdel-Aziz, M.; Ahmed, E.; Enany, S.; Mahgoub, S.; Al-Rugaie, O.; Alsharidah, M.; Aly, M.S.A.; et al. Phytochemical Profiling, In Vitro and In Silico Anti-Microbial and Anti-Cancer Activity Evaluations and Staph GyraseB and h-TOP-II $\beta$ Receptor-Docking Studies of Major Constituents of Zygophyllum coccineum L. Aqueous-Ethanolic Extract and Its Subsequent Fra. Molecules 2021, 26, 577. [CrossRef]

29. Shaheen, U.; Ragab, E.A.; Abdalla, A.N.; Bader, A. Triterpenoidal saponins from the fruits of Gleditsia caspica with proapoptotic properties. Phytochemistry 2018, 145, 168-178. [CrossRef]

30. Vermes, I.; Haanen, C.; Steffens-Nakken, H.; Reutellingsperger, C. A novel assay for apoptosis flow cytometric detection of phosphatidylserine expression on early apoptotic cells using fluorescein labelled annexin V. J. Immunol. Methods 1995, 184, 39-51. [CrossRef]

31. Nicoletti, I.; Migliorati, G.; Pagliacci, M.C.; Grignani, F.; Riccardi, C. A rapid and simple method for measuring thymocyte apoptosis by propidium iodide staining and flow cytometry. J. Immunol. Methods 1991, 139, 271-279. [CrossRef] 